\title{
Maintaining students' Speaking Fluency through Exhibition Examination in Sociolinguistic Studies
}

\author{
Khusnul Qhotimah Yuliatuty \\ English Department, Faculty of Education \\ Universitas Siswa Bangsa Internasional \\ Indonesia \\ E-mail: khusnul.qhotimah@sampoernaeducation.net
}

\author{
Doi:10.7575/aiac.alls.v.4n.2p.13 \\ URL: http://dx.doi.org/10.7575/aiac.alls.v.4n.2p.13
}

Received: 03/04/2013

Accepted: 04/06/2013

\begin{abstract}
Using exhibition for the final project in Sociolinguistic study is really interesting for Universitas Siswa Bangsa Internasional students, especially for 2011 English Department students. Exhibition becomes interesting because this is the new thing to conduct the final project for English Department students' cohort 2011 at Universitas Siswa Bangsa Internasional. The lecturer divides the students into pairs and each pairs should master one content or topic in Sociolinguistic study. The students will do the exhibition about the topic that they get in a pairs. The lecturer also gives the students rubric sheet to fill by the visitors. The exhibition will make the students prepare themselves well because they will face many questions about the content which will be delivered by them. Beside, this exhibition also maintains students' fluency in speaking English because they will explain and answer the questions from visitors with English. This paper tries to focus on how exhibition examination can maintain students' fluency in speaking English.
\end{abstract}

Keywords: exhibition, examination, students' speaking Fluency

\section{Introduction}

Most of English department student's cohorts 2011 at Universitas Siswa Bangsa Internasional (USBI) are having good fluency in English writing, however they still lack in speaking. Basically, the students know about an English grammar but in the other hand, the students still confused to use and implement the grammar in speaking. In this research, the researcher can conclude if the students more fluency in writing English by observing how the students writing a text in English. Because of the research wants to see the students' writing fluency, so the researcher only observe the surface of writing not on the progress of writing. There are some factors that influences students speaking fluency, they are lacking of language aptitude, lacking of motivation, and lacking of confidently (Noonan, 2005). Then, in this phenomenon the lack of students' confidence is become the most factor that influence students speaking fluency. As Benny (2013) said that the language learners can never speak a language if they only studying it and they never start to speak, that is why there so many ways to boost students' speaking fluency in this campus and some of the ways give the chance to increase students' confidence. The most interesting way to maintain students' speaking fluency at USBI is using exhibition examination. Actually there are still many interesting ways which use to maintain students' speaking fluency at USBI, but here the writer tries to observe and explore about Exhibition examination in Sociolinguistic final exam.

In the Sociolinguistic class at the Universitas Siswa Bangsa Internasional University, the lecturer helps the students in maintaining students' speaking fluency by doing exhibition examination. Since motivating the students to speak English fluently is difficult, the lecturer uses some good unpredictable ways to maintain students' speaking fluency and one of the ways is using exhibition for final examination. Where the lecturer gives the students a topic to present by using a poster, and makes environment almost the real exhibition, and divided the students into pairs to do the exhibition examination also mentioned by Revayee (2009) who says "The best way to motivate the students to speak is to have more pair and group works" Maintaining students' speaking fluency by using a group work also supported by Kandy (2009) said "The best ways to make people speak are using a pair work and placing a friendly situation".

\section{Statement of the Problem}

In this research the researcher wants to investigate the phenomena which happened in Universitas Siswa Bangsa Internasional which use the exhibition examination to maintain students' speaking fluency.

3. Objectives

-To know how the exhibition examination in sociolinguistic study maintains the students' speaking fluency in English for ESL learners is.

-To know the advantages and disadvantages of using exhibition examination for students' speaking fluency.

\section{Research questions}

The literature review on exhibition examination and concepts on students' speaking fluency brings forward the following research questions: 
1. How the exhibition examination does maintain students' speaking fluency?

2. How is the relationship of exhibition examination to students' speaking fluency?

\section{Literature review on Exhibition Examination}

Commonly, exhibition is an activity to show arts or something good to the public (Webster, 2013). The exhibition in traditionally is the space to exhibit the arts objects meet an audience (Bethesda, 2001). He also said that exhibition divided into two types; there are commercial exhibition and non-commercial exhibition. The commercial exhibition is arts fair that the people have to pay to see the exhibition, but in non-commercial exhibition the people do not have to pay to see the exhibition. In this research phenomena exhibition is an activity to exhibit and explain the materials of the study course to the public in a form of poster. For this case, the students will divided into a pair and they will make a poster which describes a topic that they have learned before, and this way is become one of the activities for the final test or examination. The assumption says that this activity can maintains students' speaking fluency, that is why the researcher wants to elaborate weather the assumption is true or not.

\subsection{Literature review on Students' Speaking Fluency}

Speaking fluency is the ability to speak smoothly and expressively in order the speaker can understand and respond in a language clearly and concisely while relating meaning and context (Koshthip, 2011). From that definition of speaking fluency, the writer concludes that in speaking fluency the students can eliminate the accuracy as long as they can speak clearly and smoothly and also get the meaning from what they have said. This argument also supported by Koshtip (2011) who said "usually those learner who pay attention to the grammar, they become good in accurate speaking. For those who pay attention to words or vocabulary they become fluent speaker and if you concern in fluency so, let them speak and do not pay attention to their accuracy". Al-Sabai (2004) suggest that "a person is said to be a fluent speaker of a language when he can use its structures accurately while concentrating on content rather than form" she also said that fluency is "the features which give speech the qualities of being natural and normal, including native-like use of pausing, rhythm, intonation, stress, rate of speaking, and use of interjections and interruptions."

\subsection{Literature review on Maintaining students' fluency in Speaking English by Exhibition Examination}

Kluge et al. (1999) "to give students more fluency practice, students are required to do conversation in pair work and give students some topic for discussing. When they are doing conversation, they stay in English and it makes them practice their fluency in Speaking English". This statement also supported by Benny (2013) "when you study English, you acquire vocabulary, you improve your grammar and you do exercise. Logically it's enough, because your level will improve then but why are you not ready to speak confidently? To make you confidence in speaking English you have to speak with others not only studies". Based on the experts' theory, the researcher concludes that the methods to maintain students' fluency in speaking English are cover in Exhibition. These arguments also supported by F.J Noonan( 2005) who said that the role of communication is the most important part of gaining students' speaking fluency because when a fluent speaker and a less fluent speaker interact, they enter into a negotiation of meaning. As they use the situational context, repetitions, and clarifications to maximize comprehension.

\section{Data Collection}

For this research, the researcher uses the study case approach in qualitative method. The researcher's reason to use the case study is because the phenomena that the researcher investigates happen in one place. The exhibition examination a phenomenon happens which the researches investigate places in Universitas Siswa Bangsa Internasional, Indonesia since 2011. With this research, the researcher also wants to elaborate how the exhibition examination maintains USBI (Universitas Siswa Bangsa) students' speaking skill, so this research conducts in a particular place. For the data collections, the researcher uses interview to students in 2011 cohort from English Education Department. The participants of this research are choses randomly, there are 53 students in this cohort who were did the exhibition examination, and the researcher took 10 students for interviewing. Besides doing interview, the research also did the forum group discussion (FGD) with the Sociolinguistic

lecturer who is conducted the exhibition in his studies. These are some example of students' opinion about exhibition examination to students' speaking fluency.

"The Sociolinguistic Exhibition improves my speaking fluency because during the exhibition I have to explain and exampling the material and I should do it because it is assessed. Even it forced me to speak but it is kind of challenges in maintaining my speaking fluency, therefore I force myself to speak a lot and that's why exhibition examination improves my speaking fluency" Students 1

"Through the exhibition I can improve my speaking fluency, because by making my visitors understand about my presentation it motivates me to practice my speaking fluency" Students 2

"In exhibition, I spoke a lot to people so automatically my speaking will be improved that's why practice make perfect"

\section{Students 3}

"Exhibition encourages me to speak more because I need to present my topic to the people and I have to practice to be fluent and accurate in presenting my topic" Students 4

"Sociolinguistic Exhibition was such a fun kind of assignment for me. There was no pressure in doing them, unlike paper and pencil test. Exhibition can improve my speaking fluency because at that day there were so many visitors came to my spot and I explained a poster to them over and over again and that increased my speaking fluency" Students 5

\section{Data Analysis}

For student 1 exhibition examination really helpful her in learning target language. She thought that although the exhibition examination forces her to speak English a lot and fluently because of the assessment, but that strategy can improve her speaking fluency. The same opinion also come from student 2 who said that exhibition examination makes 
him motivated in speaking English fluently. For him the satisfaction from the visitors is number one so, for covering the visitors' satisfaction he tried hard to do speaking practice a lot in order to fulfill the visitors' need. Because of his speaking practice, he could do the exhibition fluently. The point of view from student 3 also supported these two interview results. In preparing the exhibition, she practices speaking English often. She really want to see perfect in explaining the material to her booth's visitors. Finally, she got her dream she could speak English fluently and her practice makes her perfect. The student 4 sees the exhibition as one of way to encourage her speaking fluency. She thought with speaking English it can boost her motivates in both speaking fluency and accuracy. For student 5, the exhibition examination is such a fun activity for him. No paper and no paper pencil test becomes his reason to say that exhibition examination is a fun examination. He also stated that exhibition maintain his English speaking fluency, because in exhibition he explained the material again and again and directly it can improve his speaking fluency.

\section{Findings}

Based on five students' opinion above, it is clear that exhibition examination is really helpful the students to maintain their speaking fluency. The exhibition examination leads the students' interest and motivation in learning English because by presenting the materials over and over again will help students to memorize the new vocabularies easier. That argument also endorsed by Baddely et al (1998) who find Phonological loop variables which help students to acquire the new vocabularies by repeating the new word over and over again in order the words stored in mental lexicon permanently. As the students have a lot of new vocabularies, it will support their speaking fluency. When the students are having exhibition examination they will practice and present their material to the visitors and it means the students will memory and repeats some new vocabularies. With the rich of new vocabularies it's really help the students to speak fluently and minimize the alteration in speaking.

\section{Conclusion}

Foreign language teacher need effective and interesting teaching technique to maintain their students speaking fluency. The exhibition examination is one of the ways to increase students' motivation to speak and it will give chance for the students to maintain their speaking fluency. The use of exhibition examination is really beneficial for both students and lecturer because for the students exhibition is kind of fun assignment where students can meet people and present their creative poster and the lecturer only collects rubric which have filled by the visitors for scoring the students' presentation Since the exhibition examination experiences help the students to improve the students' speaking skill, the lecturer has to be more creative and careful to choose the material for exhibition in order the student will not bored with the exhibition environment which will keep students' motivation to maintain their speaking fluency.

\section{References}

Al-Sibai, D. (2004). Promoting Oral Fluency of Second Language Learners. Oral Fluency.

Benny. (2013). Why Studying will never help you? Dipetik Spetember 2013, dari Fluent in 3 months: www.fluentin3months.com

Bethesda. (2001). Environmental Conditions for Exhibiting Library and Archival Material.

Council, B. (2009). Motivate Students to Speak Fluently. Dipetik September 203, dari Teaching English: www.teahingenglish.org.uk

David E. Kugle, M. A. (1999). Boosting Speaking Fluency Through Partner Taping. TESL Journal.

Noonan, F. (2005). How to Improve English.

Revayee, A. A. (2009). Motivate Students to Speak. 54. 